\title{
Studies in the Development and Morphology of Cycadean Sporangia :
}

I. The Microsporangia of Stangeria paradoxa.

BY

WILLIAM H. LANG, M.B., B.Sc.,

Lecturer in Botany, Queen Margaret College, Glasgow University.

\section{With Plate XXII.}

THE especial interest which attaches itself to the Cycadaceae as forms occupying an intermediate position between Phanerogams and Cryptogams has been dwelt on by several investigators who have studied these plants, and has recently been increased by the discovery of zoidiogamic fertilization in one genus (Cycas) ${ }^{1}$, and of striking anatomical resemblances in the vegetative organs between another genus (Stangeria) ${ }^{2}$ and the long extinct group of Lyginodendreae.

These considerations justify a fuller examination and account of the existing genera of Cycads than would be necessary in the case of plants of less importance from the point of view of descent : this may provide a basis for comparison of the living representatives of the group among themselves, and with such fossil remains of related plants as may be discovered. The need of this from the palaeobotanical side has been emphasized by Seward ${ }^{3}$.

1 Ikeno, Bot. Centralb., I897, p. I.

${ }^{2}$ Williamson and Scott, on Lyginodendron and Heterangium, Phil. Trans. Roy. Soc., 1895, p. 768. See also Scott on Peduncle of Cycadaceae, in the present number of the Annals of Botany.

${ }^{3}$ Science Progress, N. S., Vol. i, p. I 18.

[Annals of Botany, Vol. XI. No. XLIII. September, I897.] 
In these studies the attempt will be made to examine and compare the development and mature structure of the sporangia of those Cycads that have not been fully investigated, so far as material can be obtained. The difficulty of obtaining suitable material for developmental work is very great in plants of this group; but the magnificent collection of Cycads in cultivation at the Royal Gardens, Kew, which in many cases bear cones freely, affords a peculiarly favourable opportunity for gradually accumulating material of the various stages. This investigation was commenced at the suggestion of Dr. D. H. Scott in the Jodrell Laboratory at Kew, upon material already collected by him: and this material was supplemented with further stages as opportunity offered. In connexion with the collecting of material, I wish to acknowledge my indebtedness to the authorities of the Royal Gardens, who, whenever possible, readily gave me permission to preserve the cones which were produced on the different species. The removal of young cones without inflicting injury on the plants is an operation that requires great care, and in this and other ways Mr. Watson kindly assisted me.

The work was commenced under the guidance of Dr. Scott in the Jodrell Laboratory, and has been continued at Glasgow University. To Dr. Scott and Dr. Bower I wish to express my thanks for numerous suggestions and other valuable assistance in the course of the investigation.

Two courses are open in recording the results obtained. The observations made on the considerable amount of material of a number of genera might be collected together, and supplemented when the stages which were wanting could be obtained; or the publication of the results on each genus might be deferred until a fairly complete account of the development of its sporangia was possible. The latter course has many advantages, and will be followed.

The present paper deals with the development and structure of the microsporangia of Stangeria paradoxa, Th. Moore. Since it has not been possible to obtain the earliest stages of the development of the ovule, the full account of its de- 
velopment and structure is deferred in the hope of obtaining cones of the required age.

The resemblance which Stangeria presents in general habit to a Fern is striking, and has been frequently referred to. In the light of other facts, which make the origin of the Cycads from Fern-like ancestors probable, considerable importance may be attached to this; and it is possible that, in the appearance of the vegetative organs, Stangeria presents primitive and not secondarily acquired characters. The fact that structural peculiarities of morphological importance, which in other Cycads are confined to the leaves, have been found in the peduncles of both male and female cones of this species $^{1}$, made it a matter of some interest to ascertain whether Stangeria differs from other Cycads in the structure and development of its sporangia.

The material was obtained from a large plant, growing in the Victoria regia house at $\mathrm{Kew}$, which produces numerous male cones. A series of these, from the first appearance of the tip of the cone among the scale-leaves covering the apex, to the mature cone with dehiscing sporangia, was collected.

The mature sporophylls ${ }^{2}$ are inserted on the axis of the cone by short stalks. Each consists of a horizontal portion, the lower surface of which is closely covered with sporangia, and which is continued into the scale-like terminal part. This is clothed with hairs on its outer surface, and is almost vertical, overlapping the sporophylls immediately above, and affording efficient protection to the sporangia during their development. A slight depression in the outer margin of the area covered with sporangia indicates its origin by the junction of two lateral groups of sori. The sporangia differ somewhat from one another in size and shape. A row of large oval sporangia can always be distinguished at the outer margin, and within this is a similar but less regular row; these two rows of sporangia correspond to the outer row of sori. The other sporangia are slightly smaller, and are arranged in sori,

\footnotetext{
${ }^{1}$ Scott, loc. cit.

${ }^{2}$ Figured in Bot. Mag., Vol. 85 , Pl. 5121.
} 
which consist of two to seven sporangia. These sori are difficult to detect in the mature cone, but sometimes the direction of the long axes of the crowded sporangia and of their lines of dehiscence, which run radially in the more regular sori, enable their limits to be determined. As serial sections in a plane parallel to the surface of the sporophyll show, the stalks of the sporangia composing a sorus converge as the surface of the sporophyll is approached. In the intervals between the sori hairs are present, while they are not found between the individual sporangia of a sorus. Each sporophyll bears a large number of sporangia ${ }^{1}$; these are less numerous on the scales near the apex of the cone, but their arrangement is the same.

The youngest cones that could be obtained without risk of injury to the plant were too far advanced to enable any observations on the development of the sporophylls to be made; they measured $28 \mathrm{~mm}$. in length, exclusive of the peduncle. The early stages of development of the sori and sporangia could, however, be followed in cones of this size, for not only were the sporophylls in the apical region in a less advanced stage of development than those inserted nearer the base, but sori of different ages were present on the same sporophyll.

The young sporophyll (Fig. I) has a short stalk. The horizontal soriferous portion is distinguishable by its white glistening appearance from the hairy surface of the terminal scale-like part, which extends as a $\mathrm{V}$-shaped projection between the two lobes of which the horizontal portion consists, but does not completely separate them. The sori in the youngest scales examined formed a slightly curved row on each side, immediately within which was a group of sori differing in size from one another. The outer row of sori gives rise to the two outer rows of sporangia, while the inner group consists of the first developed sori of more central sporangia. These are seen to be distinct from one another in older scales

1 According to Al. Braun more than 100 (Die Frage nach der Gymnospermie der Cycadeen : Monatsber. d. K. Akad. d. Wiss., Berlin, I875, p. 343, note). 
(Fig. 2). The part bearing the sori has increased in size, and its lateral lobes are more prominent. Sori continue to arise toward the outer border of the lateral lobes, and also on the elevated median ridge. As the latter increase in number, they connect the two groups of sori which were at first separated by a considerable interval. Those last formed are the most regular in form; they arise as circular elevations, the margins of which soon become distinct, and they are at first separated from one another by wider intervals than the earlier formed sori. The appearance presented by the latter (Fig. I) suggests an origin by unequal growth of a slightly elevated central region.

The differentiation of the sorus into sporangia agrees closely with what takes place in Ceratozamia. On the same sporophyll all stages from the first indication of a sorus to sporangia of considerable size are present (Figs. 2, 3), while Warming's figures suggest that the numerous sori on any sporophyll of Ceratozamia are at the same stage in their development ${ }^{1}$.

One peculiar feature in the relation of the individual sporangia of a sorus to each other is best illustrated by a transverse ${ }^{2}$ section (Fig. 4). In many cases the sporangia become equally distinct from one another at an early stage, but sori were frequently observed, in which some or all of the sporangia remained for a time united in pairs. In the sorus figured three such pairs are seen, the crosses indicating the position of the sporogenous groups of cells, which were similar to that shown in Fig. 8.

The superficial cells of the region of the sporophyll, on which sori are about to arise, have larger nuclei and more abundant protoplasm than the underlying ones. The epidermis is a perfectly definite layer dividing only by

${ }^{1}$ Warming, Contrib. à l'histoire naturelle des Cycadées, Copenhagen, I879, Tab. V, Figs. 2, 4, 8, 9, 10.

${ }^{2}$ By a transverse section of a sorus or sporangium is meant one parallel to the surface of the sporophyll. A surface perpendicular to the surface of the sporophyll will be spoken of as a vertical section and, when possible, will be distinguished as radial or tangential with reference to the sorus. 


\section{Lang:-Studies in the Development and}

anticlinal walls. The sorus appears as a slight elevation, which is at first flat-topped, but at an early stage becomes depressed centrally by the more rapid growth of the surrounding cells. The origin of the sorus depends, partly on the increase in size of the cells of the hypodermal layer, and partly on division and growth of the cells underlying this. Sometimes the latter owe their origin to earlier divisions of the hypodermal layer, in which case a section of the sorus shows vertical rows of cells; in other sections this is not so obvious. The merismatic appearance of the tissue extends more deeply beneath a developing sorus than elsewhere, and in a slightly later stage is seen to be continuous with the procambial strand of the bundle, which terminates beneath each sorus. In radial sections of such young sori certain hypodermal cells of large size and with prominent nuclei can be recognized. They occupy a definite position, about midway between the depressed centre and the margin. Usually two such cells are visible in a vertical section passing through one of the young sporangia (Fig. 5), but comparison with the adjoining sections of the series and with transverse sections of sori of similar age shows that a group of four cells is present, only two of which can appear in a vertical section. From this group of cells the sporogenous tissue is derived. The frequency with which anticlinal divisions take place in the hypodermal layer renders it a matter of great difficulty to determine whether this group is derived from a single cell, as Goebel ${ }^{1}$ suggested in the case of Zamia, or not. In certain cases I am of opinion, from a careful study of the arrangement of the cell-walls, that this is not the case, but in a few examples it appeared to be a possible interpretation. No single cell could, however, be distinguished as occupying the position of the cell-group in younger sori.

Each of the four cells undergoes division by a periclinal wall into a flat outer cell and an inner one of slightly greater size (Fig. 6). From the four inner cells thus produced the sporogenous tissue is derived. Their origin is similar to that

${ }^{1}$ Goebel, Vergleich. Entwicklungsgesch. d. Pflanzenorgane, p. 395. 
of the archesporial cells in the pollen-sac of an Angiosperm, while the outer segments correspond to the primary tapetal cells.

The first division in the sporogenous cells is by a periclinal wall, so that a group of four cells is seen in a vertical section (Fig. 7). Since four sporogenous cells are visible in transverse sections of sporangia of this age (Fig. 8) it is clear that there is a cubical group of eight cells. The cells surrounding each sporogenous group keep pace with its increase in size and undergo frequent divisions. At the central point of the sorus and between the developing sporangia the hypodermal cells soon lose their merismatic character and cease to grow, so that the sporangia become distinct from one another. In such cases as that shown in Fig. 4, growth has not been arrested in the interval between the sporangia of each pair, but these also become free from one another at a later stage. The stalk of the sporangium is derived from the growth of the tissue beneath the sporogenous group.

After the stage represented in Fig. 7 has been reached, the divisions in the sporogenous cells do not follow in exactly the same order in different sporangia. Usually each of the upper cells is divided by anticlinal walls, and the resulting cells undergo periclinal divisions. From the lower of the shaded cells seen in Fig. 7 the greater part of the sporogenous tissue originates: these cells divide, in the more regular examples, into four by periclinal and anticlinal walls. The subsequent divisions of these cells occur in various directions, but the position of the earlier division walls remains traceable for some time (Figs. 9, 10). In transverse section the whole of the sporogenous mass can as a rule be referred to the group of four cells present in similar sections of younger sporangia (Fig. II).

The shape of the sporogenous group differs to a considerable extent in sporangia of the same age, as will be seen on comparing Figs. 9 and 10 . These differences stand in relation with the general form of the sporangium, which appears to be influenced in no small degree by the pressure to which it is G $\mathrm{g}$ 


\section{Lang.--Studies in the Development and}

subjected during development. That the pressure is considerable is indicated by the manner in which the upper surface of the sporophyll becomes marked by small depressions corresponding to the sporangia of the sporophyll above. When this pressure acts upon a sporangium, the form assumed at this stage is short and broad, the sporogenous tissue is extended parallel to the flat top of the sporangium, and the cells of the wall which owe their origin to the primary tapetal cells are flattened (Fig. 9). It sometimes happens, however, that by the presence of large sporangia around, or by the margin of the sporophyll becoming turned down to form a sort of rim, the sporangium is almost relieved from pressure in the vertical direction. It then assumes the form shown in Fig. 10, where the sporogenous tissue forms an elongated square prism retaining the general proportions seen in Fig. 7 ; the general form of the sporangium is correspondingly elongated, and the cells of the wall derived from the primary tapetal layer have not the flattened appearance seen in the former example.

The sporangium increases considerably in size without any further differentiation becoming apparent. A large mass of sporogenous tissue is formed by repeated divisions, and the wall increases in thickness (Fig. I2). The thickness of the wall is usually greater on the side toward the centre of the sorus and the rectangular outline of the upper part of the vertical section is due to its thickness at the angles. At the sides it consists of four or five layers of cells. At this stage the epidermal cells are still thin-walled. The cells adjoining the sporogenous mass usually divide by walls parallel to the limits of the latter, and the more or less complete double layer thus produced is distinguishable even in the mature sporangium. This layer, the further development of which will be described below, forms a convenient indication of the limit between the wall and the sporogenous tissue.

Until this stage (Fig. I 2) the tapetum is not recognizable, but shortly after the divisions in the inner layer of the wall its origin can be traced. It arises from the sporogenous tissue 
by the cutting off of tabular cells from the outer layer or, less commonly, by the direct conversion of the outer cells into cells of the tapetum. Fig. I 3 shows the tapetal layer at this stage, and demonstrates, both by the arrangement of the cellwalls and by its position with regard to the double layer of cells of the wall, that it has arisen from sporogenous cells. Usually the tapetum is a single layer, but it may become at places two or even three cells thick, by the deeper cells of the sporogenous mass assuming the characters of tapetal cells. Its cells at first resemble those of the sporogenous tissue so closely that care is necessary to distinguish them, but changes soon occur in the latter which render their distinction an easy matter, and, by comparison with earlier stages, place their mode of origin beyond doubt. The sporogenous cells are now the mother-cells of the pollen-grains, and their walls undergo a change which causes them to stain deeply with Bismarck-brown, while the walls of the tabular tapetal cells remain thin and are more difficult to distinguish than before. Comparison of a large number of sporangia shows that the mode of origin of the tapetal layer described above is the ordinary one in Stangeria; but I am not prepared to state that this layer is never derived in part from cells adjoining the sporogenous tissue, although no sporangium in which this was clearly the case has been found.

Immediately outside the tapetum the double layer of cells can in most cases be recognized. Its cells are usually flattened and contain elongated nuclei which appear homogeneous and highly refractive. Between these cells and the epidermis, the cell-walls of which are becoming thickened, the remaining layers of the wall are present. Their nuclei as a rule do not take on the same highly refractive appearance as those of the double layer of cells.

Some of the spore-mother-cells do not develop further, but undergo a change closely resembling that described by ' ${ }^{\prime}$ reub ${ }^{1}$ in Zamia, both nucleus and cytoplasm becoming highly

${ }^{1}$ Recherches sur les Cycadées: Ann. Jard. Buitenzorg, Vol. ii, p. 36, P1. III, I, 4,5 .

$$
\text { G g } 2
$$




\section{Lang.-Studies in the Development and}

refractive and undistinguishable from one another; these cells stain deeply and uniformly (Fig. I4). The number of cells that undergo this sterilization is not great, but the fact of its occurrence is of interest, for comparison with what takes place in the large sporangia of Pteridophyta, e.g. Equisetum ${ }^{1}$, Psilotum $^{2}$, Ophioglossum ${ }^{3}$, and in the pollen-sacs of some Angiosperms, e.g. Arum maculatum. The sterilized cells are always much smaller than the surrounding sporogenous cells with which they agreed in size before the change commenced. This circumstance, taken together with the fact of the sterilized cells being more or less flattened in most cases, suggests that increase of pressure within the sporangium is at least a factor in their production. It is of interest in regard to this to note that at the time of their appearance the epidermal layer has just acquired its thick walls, which may be presumed to offer greater resistance to the increase in size of the sporogenous mass within. It is possible that deficient nutrition may be another factor in their production, but their frequent occurrence close to the tapetum itself points to the operation of some other cause.

The spore-mother-cells become isolated from one another. The tetrad-division was not followed in detail, but the tetrads still enclosed in the wall of the mother-cell closely resemble those of other Cycads. Fine granules are present between them, but only in small amount. The spherical spores, when they become free, do not nearly fill the cavity of the sporangium (Fig. I5).

The tapetum persists as a complete layer within the wall of the sporangium; its cell-walls have disappeared. The individual cells stain deeply; each possesses a nucleus which never assumes the highly refractive appearance of the layer immediately outside. The nucleus often breaks up into two or three, apparently by fragmentation.

1 Bower, Phil. Trans. 1894, p. 500, Fig. 2 I, Pl. 43.

2 Ibid. p. 550, Fig. I 43, Pl. 5I.

3 Rostowzew, Recherches sur l'Oph. vulg., note préliminaire, p. 2 $\$$, Taf. I, Figs. 1, 5 . 
The two layers of cells, the origin of which from the cells of the wall adjoining the sporogenous mass was described above, are now so crushed that the limits of the cells are difficult to make out, and the whole appears under low powers as a thin band outside the tapetum (Fig. I5). The cells of this layer stain deeply, and are sharply distinguished from the outer cells of the wall, which have oval nuclei of granular appearance. There are three to six layers of these cells and the wall is bounded by the epidermis, the cells of which differ in form and structure according to the part they play in the dehiscence of the sporangium.

When examined from the surface, the epidermal layer is seen to consist of cells with more or less thickened walls, elongated in the direction parallel to the line of dehiscence. The latter is distinguished by its colourless cell-walls, which contrast with the brown colour of the cells of the rest of the wall. Its cells, which form two rows, are somewhat shorter than those on either side; they have greatly thickened walls in which numerous simple pits are present. The line of dehiscence extends along the whole length of the side of the sporangium which is turned away from the sporophyll; it reaches from close to the stalk almost to the apex, where it is continuous with a group of cells which agree with it in the appearance and structure of their walls, but have more or less circular cavities. These cells which occupy the apex, correspond in position, as Warming has stated ${ }^{1}$, to what is usually described as the annulus of Osmunda or Angiopteris. In Stangeria they do not project above the level of the surrounding cells, though this is the case in some other genera of Cycadaceae ${ }^{2}$. The apex of the sporangium of Stangeria corresponds closely with that of Ceratozamia. The cells of the rest of the sporangial wall have cell-walls of a yellow colour and of considerable thickness. When viewed from the outside but little difference can be detected between them: the cells near to the line of dehiscence have, however, some-

\footnotetext{
1 Warming, loc. cit. p. I, Pl. V, Fig. 12.
}

2 Treub, loc. cit. p. 37, Pl. III, Fig. 2. 


\section{Lang.-Studies in the Development and}

what thicker walls with more numerous pits than those toward the opposite side of the sporangium. If a section of a sporangium at right angles to the line of dehiscence be examined, the difference is found to be much more considerable than appears in surface view. The cells for some distance on either side of the line of dehiscence have all their walls, especially the inner and vertical, strongly thickened (Fig. I8). Toward the apex these bands of thick-walled cells are broader than near the stalk, and the transition from them to the thinner-walled cells of the lateral region is more gradual. The latter near the apex have thin outer but fairly thick vertical and inner walls, while further from the apex the cells become more uniformly thin-walled.

There are thus bands of thick-walled cells on either side of the line of dehiscence, which meet at the apex in the cap of isodiametric thick-walled cells, while the rest of the epidermal layer is composed of comparatively thin-walled cells. The relation of the thin- and thick-walled regions of the wall is closely similar to that existing in Angiopteris ${ }^{1}$. The mechanism by which the sporangium opens appears also to be essentially the same ${ }^{2}$. When the cells dry up at maturity, the thin-walled cells of the lateral region contract and pull upon the bands of thick-walled cells, thus widening the slit: this in Stangeria is formed by the separation of the two rows of cells which compose the line of dehiscence, while the cells themselves remain intact. The widely gaping slit, which extends from the stalk to the apex, is directed downwards in the natural position of the sporangia. The mature sporangium can be induced to open by drying, and closes again when moistened.

Numerous stomata are present in the epidermis of the side of the sporangium away from the line of dehiscence and near the stalk. Their position is indicated in Fig. 17 by dots on

2. Zeiller, Gîtes Minéraux, Flore fossile, p. I8, Fig. I 3.

2 The mechanism of dehiscence in Angiopteris is described in a paper by Bower, read before the Royal Society on May 27, 1897 , but not yet published in full. I am indebted to Dr. Bower for placing his results and preparations at my disposal for purposes of comparison with Stangeria. 
the wall. Their guard-cells are depressed below the surface, and subsidiary cells are present. The stomata do not become fully developed until the sporangium is nearly mature. They are found in a similar position on microsporangia of Ceratozamia and Encephalartos, the only genera of which mature material was at hand for comparison. Stomata are present on the ovules and sometimes the pollen-sacs of Angiosperms, but, so far as I am aware, not on the sporangia of any Vascular Cryptogam. The two sporangia represented in Fig. 17 also illustrate the difference in form between the sporangia at the outer border of the soriferous region $(\alpha)$ and those situated more centrally $(b)$; the existence of this difference was referred to above, and the figure will explain its nature without further description.

The pollen-grain of Stangeria ${ }^{1}$ is at first spherical; later one side becomes infolded, and its shape is oval. At first only one nucleus is present (Fig. I6, p), but before the pollen is shed each grain contains three cells, the large, vegetative cell with its spherical nucleus and two cells with thin cell-walls (Fig. I 8); these are situated against the side which becomes infolded. Since only these two cells were present in pollen which had been germinated by Dr. Scott, it is safe to conclude that they are the only ones cut off in the course of development of the pollen of Stangeria. Stangeria thus agrees with the other Cycads in the structure of its pollen.

The ovule of Stangeria agrees closely in the later stages of development with the Cycads examined by Warming ${ }^{2}$ and Treub $^{3}$. The embryo-sac was already present in the youngest material yet obtained; it is developed from the lowest of a row of three cells, which is derived from a single cell occupying a central position in the nucellus. The embryosac, in the ovules of this cone, was but slightly larger than

${ }^{1}$ Braun, loc. cit. p. 3I5, described the pollen-grain of Stangeria, but did not determine the number of basal cells (Basalzellen).

${ }^{2}$ Recherches et remarques sur les Cycadées. Copenhagen, I877.

${ }^{3}$ Loc. cit. 


\section{Lang.-Studies in the Development and}

the other cells of the row, and contained a single nucleus. It increases rapidly in size, and its nucleus gives rise to a considerable number of daughter-nuclei, which are situated in a layer of protoplasm lining the wall. In a further stage the embryo-sac is filled with the thin-walled tissue of the prothallus; its wall is thick and cuticularized. Surrounding the large embryo-sac in this advanced stage is a layer, one to three cells in thickness, which is all that remains of the sporogenous tissue. This layer appears to be of the nature of a tapetal layer. It persists although the cells outside it are becoming crushed as the embryo-sac increases in size, and its cells, which are frequently elongated vertically to the wall of the latter, contain in many cases two or three nuclei. If derived, as seems probable, from the outermost cells of the sporogenous mass, its place of origin would resemble that of the tapetum in the microsporangium. Further observations are required on this and other points, but the brief account given above will serve to show that Stangeria agrees closely with Ceratozamia or Cycas in the development of the embryo-sac.

\section{SUMMARY.}

I. The microsporangia are arranged in sori, the development of which is similar to Ceratozamia: sometimes the sporangia remain for some time united in pairs.

2. The sporogenous cells, usually four in number, are derived by periclinal division from cells of the sub-epidermal layer. The superficial cells take no part in their formation.

3. The tapetum arises, when the sporangium has attained a considerable size, from the outer cells of the sporogenous mass. Previously the inner layer of cells of the wall has given rise to a double layer of cells which assume peculiar characters.

4. Isolated cells throughout the sporogenous mass undergo sterilization,

5. The structure of the epidermal layer of the wall and the 
mechanism of dehiscence present close resemblances to Angiopteris. Stomata are found on the sporangium.

6. In the pollen-grain two cells are cut off from the large vegetative cell before germination.

7. In the later stages of development the ovule resembles other Cycads.

\section{CONCLUSION.}

Several observers ${ }^{1}$ have discussed the extent to which the Cycadaceae agree in the development and structure of their sporangia with the Marattiaceae on the one hand, on the other with Angiosperms. It will therefore be unnecessary to do more than point out in what respects Stangeria shows resemblances to these two groups, deferring a more detailed treatment of the subject until a larger body of facts has been accumulated. In this paper the microsporangia alone will be considered.

The arrangement of the sporangia in sori and the mode of development of the latter agrees closely with Angiopteris, and this has rendered the terms sporangia and sorus more suitable than those applied to the parts of the stamen of Angiosperms. On the other hand the origin of the sporogenous cells from the hypodermal layer, a distinct epidermis being present, is quite different from what takes place in any Vascular Cryptogam hitherto investigated; and, except for the small number of sporogenous cells, is similar to their origin in the pollen-sac of an Angiosperm. In the present state of our knowledge of the details of the apical meristems of Cycads, it is impossible to properly estimate the weight to be attached to this. If, as seems probable, the apical meristem is stratified ${ }^{2}$, no single initial cell being present, the general agreement which has been found to exist between this mode of arrangement of the formative tissues and the

1 Braun, Warming, Treub., loc. cit.

${ }^{2}$ Strasburger, Coniferen und Gnetaceen, p. 335, Taf, XXV, Fig. 36. 


\section{Lang.-Studies in the Development and}

sub-epidermal position of the sporogenous cells ${ }^{1}$ would tend to diminish the importance to be attached to this difference between Marattiaceae and Cycadaceae. It is to be noted that, though the stratification of the apical meristem was imperfect in the Cycads investigated, the stratification is perfectly definite in the young sporophyll, the epidermis never undergoing periclinal divisions.

The general agreement between the sporangia of these groups lends weight to this mode of regarding the question. The resemblance in general form and appearance between the sporangia of Cycads and Marattiaceae has been noted especially by Braun and Warming. There are two points, however, which deserve further notice, the origin of the tapetum, and the mode of dehiscence of the sporangium.

In the Marattiaceae the tapetum arises normally from the layer of the wall adjoining the sporogenous cells, and, on theoretical grounds, a similar origin might have been expected in the bulky sporangia of Stangeria. The case has been shown to be more complex, however. Three layers of cells around the mother-cells of the pollen-grains are found to have undergone special changes. The innermost layer is derived from the sporogenous mass, while the other two layers arise from the cells of the wall adjoining it. Since only the inner layer takes on tapetal characters, the tapetum has been described as arising from sporogenous cells. But the layers outside, which doubtless contribute to the nutrition of the spore-mother-cells, may possibly represent a tapetum derived from cells surrounding the sporogenous group, an additional tapetal layer having arisen from the latter. This explanation becomes more likely when it is borne in mind that other cells throughout the sporogenous mass lose the function of spore-production, and their substance aids in the nourishment of the rest. The difference in appearance of the tapetum from the isolated sterilized cells may be connected with the additional function it performs in virtue

1 Bower, Studies in the Morphology of Spore-producing Members: Ophioglossaceae, p. 7 . 
of its peripheral position. This view is only advanced as a possible way of explaining what must be regarded as an important difference between the sporangia of Marattiaceae and Cycadaceae.

The similarity in the mode of dehiscence is a necessary result of the similar development of the epidermal layer. It is interesting on account of the close agreement between Stangeria and Angiopteris in all the essential features of the mechanism, and on this account is entitled to some weight. But, since there is no evidence to show whether the presumable Fern-like ancestors of the Cycadaceae possessed separate or incompletely separated sporangia, it is equally possible that these resemblances afford rather a case of parallel development.

The general conclusion so far as the results recorded above enable it to be stated is that Stangeria shows no characters in the development and structure of its sporangia which can be regarded as primitive in any further sense than is the case for other genera of the Cycadaceae. Some details, probably common to the other Cycads, appear to be shown more clearly in this genus.

\section{EXPLANATION OF FIGURES IN PLATE XXII.}

Illustrating Mr. W. H. Lang's paper on Stangeria.

Fig. I. Under surface of the horizontal portion of a young sporophyll : a group of young sori is present on either side of the middle line. Slightly magnified.

Fig. 2. Similar view of an older sporophyll. The earlier formed sori show separate sporangia : sori are still in course of development near the middle line and towards the margin of the sporophyll. Slightly magnified.

Fig. 3. A group of sori from a sporophyll of the same age as Fig. 2, more highly magnified. To the right is a young sorus in which no indication of the sporangia is apparent.

Fig. 4. Transverse section of a young sorus; the sporangia are united in pairs. $x=$ portion of sporogenous cells. $\times 80$.

Fig. 5. Part of a vertical (radial) section through a very young sorus, showing a single sporangium : $c=$ the central point of the sorus ; $x x=$ cells from which the sporogenous cells will be derived. $\times 400$. 


\section{Lang.-Morphology of Cycadcan Sporangia.}

Fig. 6. Vertical (radial) section of a slightly older sorus, which shows two sporangia in median section : the sporogenous cells are shaded. $\times 400$.

Fig. 7. Vertical section of an older sporangium, showing the first periclinal division of the sporogenous cells, which are shaded. $\times 400$.

Fig. 8. Part of a transverse section of a sorus. The figure shows a single sporangium of about the same age as that in Fig. $7:$ the sporogenous group still consists of four cells (shaded in the figure) as seen in transverse section. $\times 400$.

Figs. 9, 10. Vertical (radial) sections of older sporangia; the sporogenous masses are shaded. These figures illustrate the difference in form that exists between sporangia of the same age. $\times 400$.

Fig. II. Transverse section of a sporangium of similar age to Fig. 9 or I0: the sporogenous tissue, which is shaded, can be referred to the four cells shown in Fig. $8 . \quad \times 400$.

Fig. I 2. Vertical radial section of an older sporangium just before the tapetum becomes recognizable : the sporogenons cells are shaded. $\times 300$.

Fig. I3. Part of a similar section of a slightly older sporangium, showing the origin of the tapetum from the outer cells of the sporogenous group. $t=$ tapetum, the cells of which are shaded ; $s p=$ sporogenous cells ; $w=$ inner part of sporangiumwall. $\times 400$.

Fig. I 4. Spore-mother-cells, one of which is undergoing sterilization. $\times 55^{\circ}$

Fig. 15. Vertical, nearly radial, section of a sporangium containing isolated pollen-grains. The tapetum is still present as a complete layer of ceils around the cavity : the cells of the wall immediately outside it are crushed : $t=$ tapetum. $\times 100$.

Fig. I6. Part of a vertical (tangential) section through a sporangium of the same age as Fig. I5, including the line of dehiscence. $e=$ epidermal layer of thick-walled cells; $t=$ tapetum ; $p=$ pollen-grains; $d=$ line of dehiscence. $\quad \times 300$.

Fig. 17. Side view of two mature sporangia: $a$, from the outer row of large sporangia; $b$, from the central sporangia. The dots indicate the position of stomata. $\quad x x=$ position of line of dehiscence. $\quad \times 6$.

Fig. 18. Ripe pollen-grain, showing the vegetative cell and the group of two cells. $\times 1000$. 
Annals of Botany
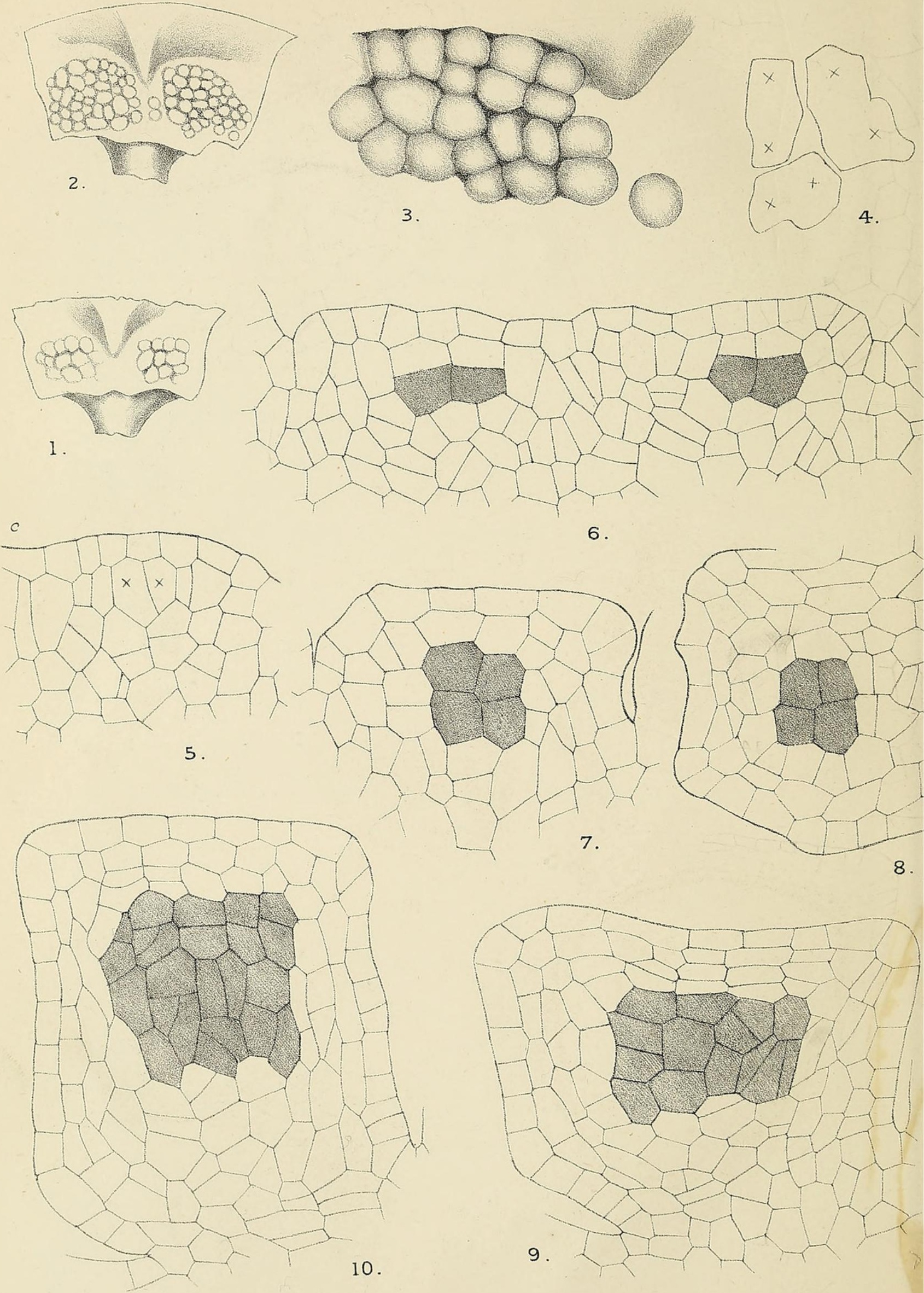

W.H.Lang, del. 
Annals of Botany

Vol.XI, PL.XXII.
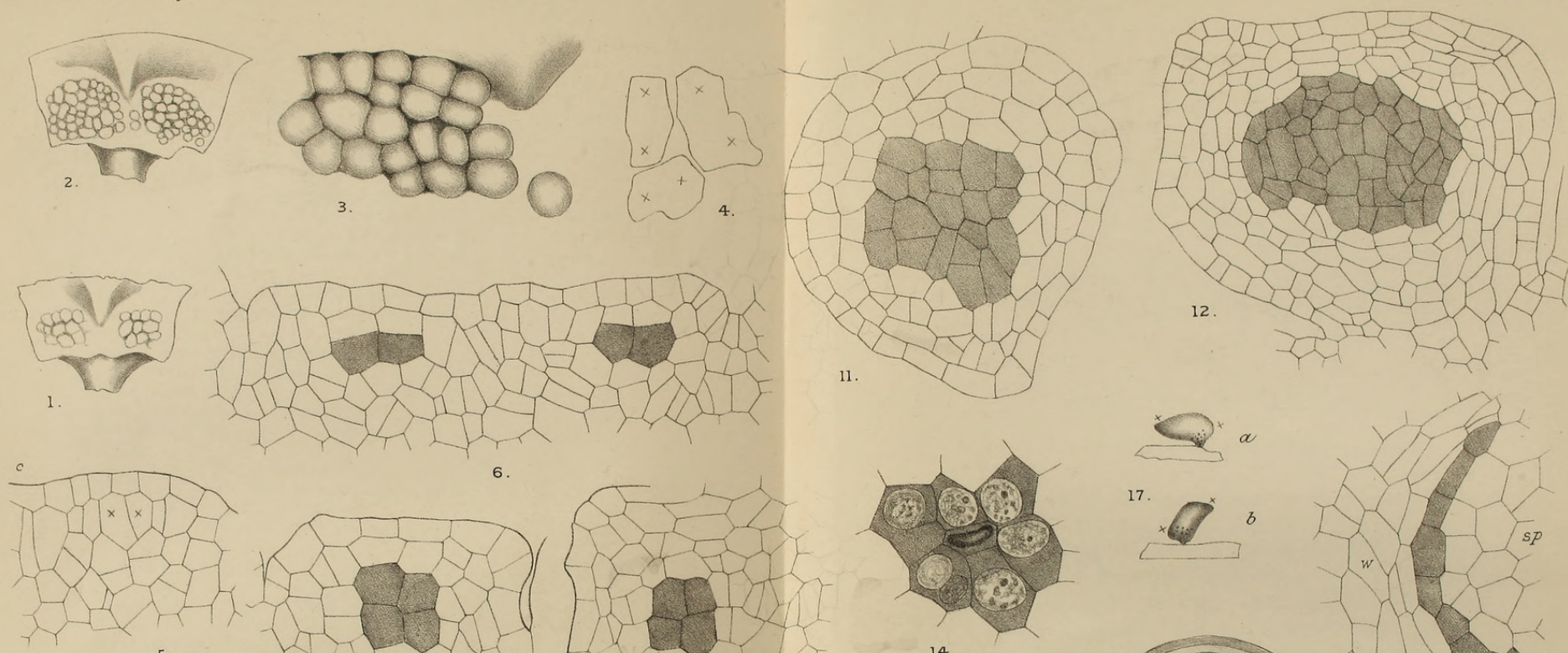

6.
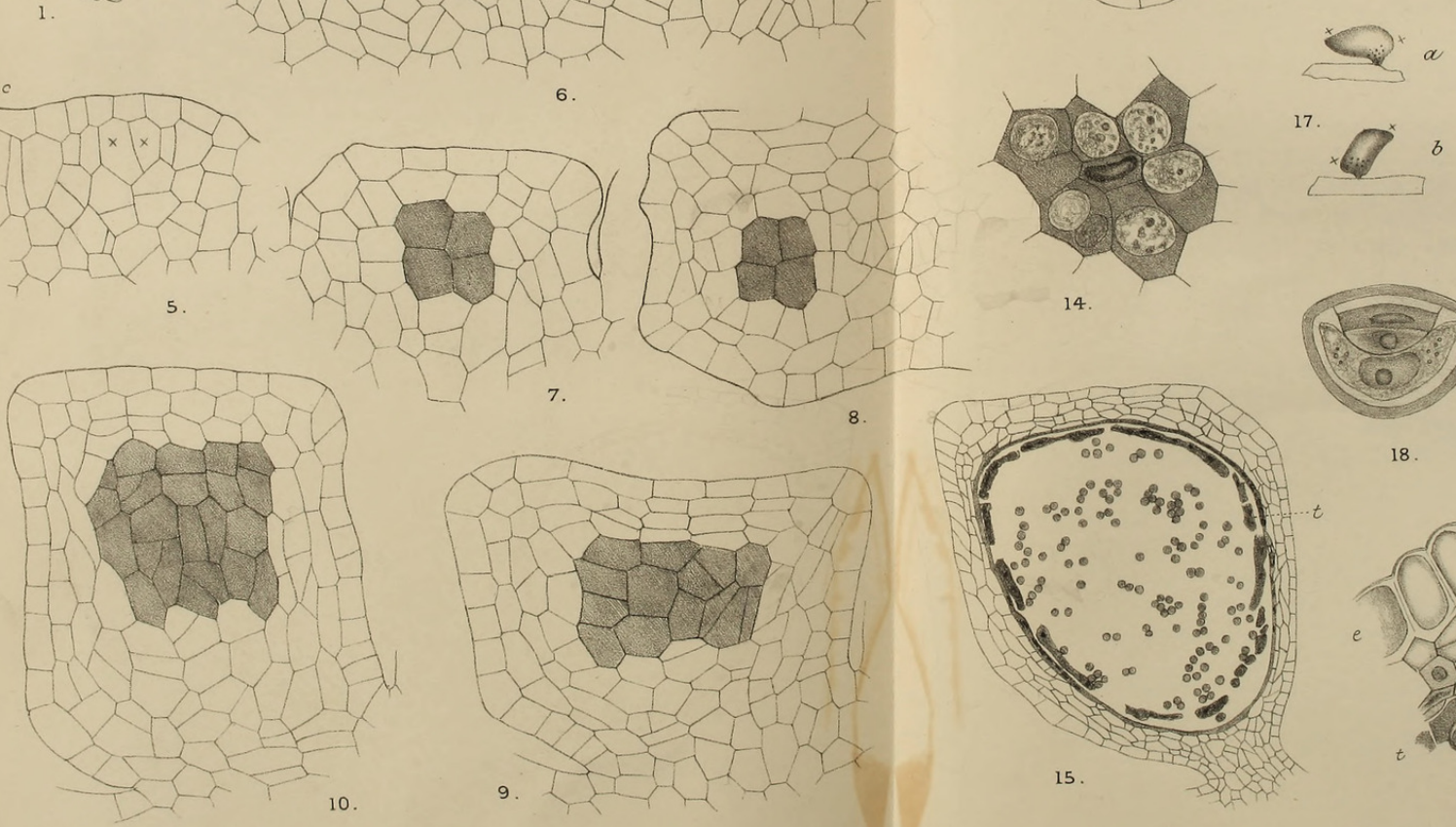

8.
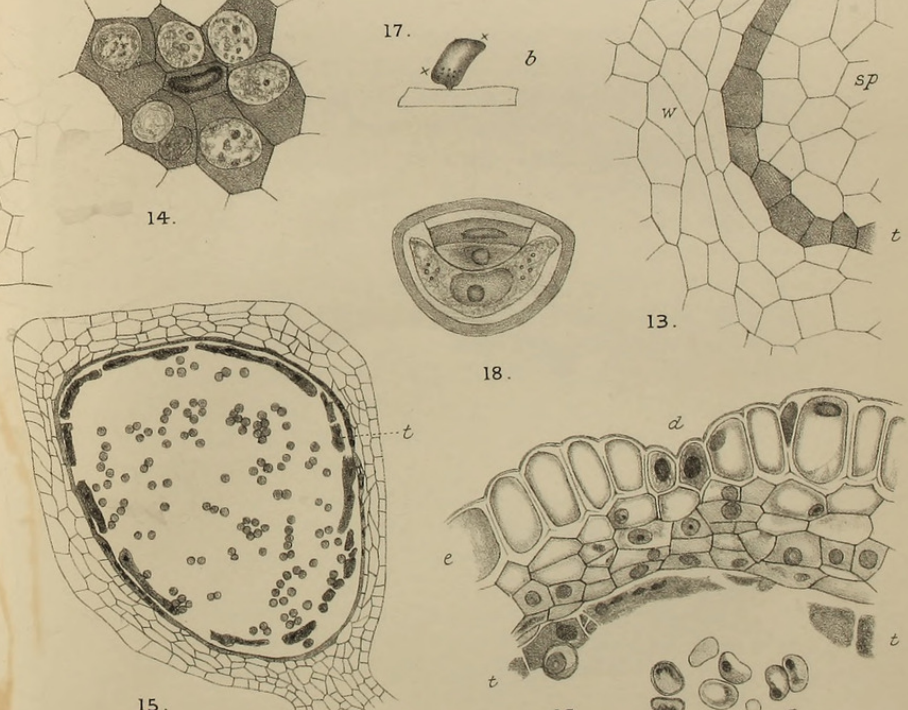

18.
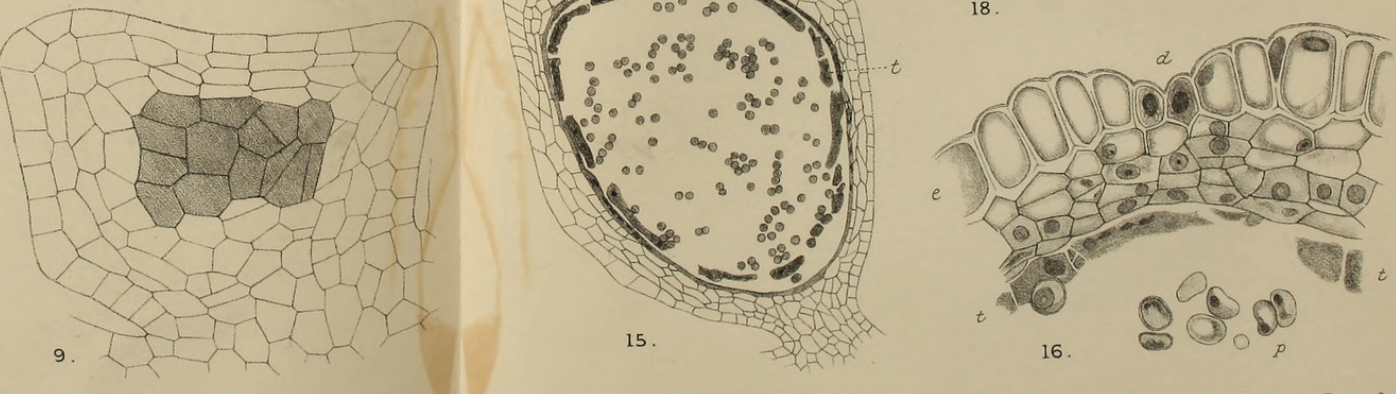


\section{$2 \mathrm{BHL}$ Biodiversity Heritage Library}

Lang, W. H. 1897. "Studies in the development and morphology of Cycadean sporangia: I. The microsporangia of Stangeria paradoxa." Annals of botany 11, 421-438. https://doi.org/10.1093/oxfordjournals.aob.a088662.

View This Item Online: https://www.biodiversitylibrary.org/item/233542

DOI: https://doi.org/10.1093/oxfordjournals.aob.a088662

Permalink: https://www.biodiversitylibrary.org/partpdf/318474

\section{Holding Institution}

Smithsonian Libraries

\section{Sponsored by}

Biodiversity Heritage Library

\section{Copyright \& Reuse}

Copyright Status: Not in copyright. The BHL knows of no copyright restrictions on this item.

This document was created from content at the Biodiversity Heritage Library, the world's largest open access digital library for biodiversity literature and archives. Visit BHL at https://www.biodiversitylibrary.org. 